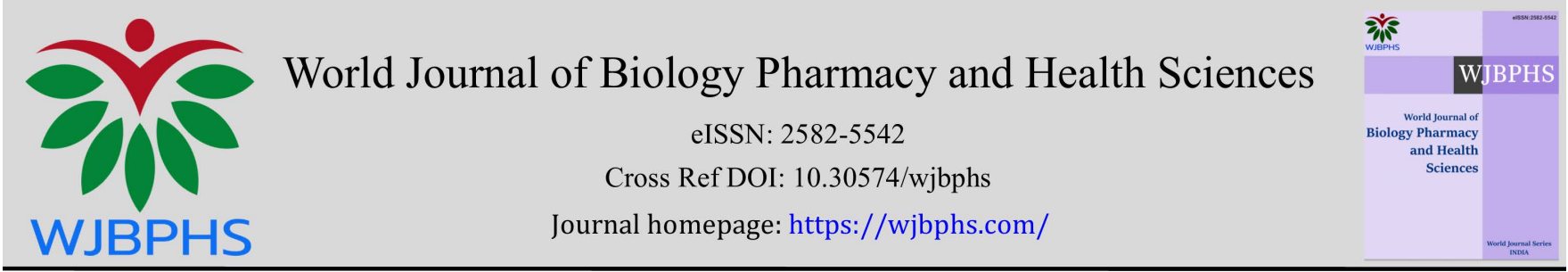

(RESEARCH ARTICLE)

\title{
Sclerocarya birrea (A. Rich.) Hochst. and Sterculia setigera Del. extracts as a potential inhibitor of Pseudomonas aeruginosa PA01 and Chromobacterium violaceum CV026 virulence factors to combat bacterial pathogenicity
}

\author{
Dramane Paré *, Jotham Yhi-pênê N'do, Vincent Ouédraogo, Abdel Magid Arsène Ouoba and Adama Hilou \\ Laboratory of Biochemistry and Applied Chemistry (LABIOCA), UFR/SVT, 09 BP 848, Ouagadougou 09, University of \\ Ouagadougou, Ouagadougou, Burkina Faso.
}

World Journal of Biology Pharmacy and Health Sciences, 2021, 05(01), 009-018

Publication history: Received on 30 October 2020; revised on 28 December 2020; accepted on 01 January 2021

Article DOI: https://doi.org/10.30574/wjbphs.2021.5.1.0075

\begin{abstract}
The abuse of antibiotics has led to the widespread development of resistant bacterial strains, there is a need for the development of antimicrobial agents with new properties.

Aim of this study was to determine the anti-quorum sensing potential (expression of virulence factor inhibition) of ethanolic extracts of S. birrea and S. setigera on Chromobacterium violaceum CV026 and Pseudomonas aeruginosa PA01.

The ability of the extracts to inhibit the production of violacein by $C$. violaceum and the biofilm formation of Pseudomonas aeruginosa was examined to determine anti-quorum sensing activity. The phytochemical screening and the determination of total polyphenols and total flavonoids were carried out. The antioxidant activity of the extracts was measured using anti-free radical DPPH model and the reducing of the ferric ion capacity.

For the inhibition of the production of violacein, S. setigera presented the best result with an inhibition of $70.19 \%$ compared to the negative control which is $1 \%$ DMSO. This inhibition is greater than that of ascorbic acid used as a reference. This species was also the most active on biofilm formation with an inhibition of $72.24 \%$ compared to the negative control, it thus showed greater activity than that of ascorbic acid used as a positive reference. The phytochemical study revealed the presence of tannin, flavonoids, triterpenes, saponosides, coumarin in our two extracts. S. birrea gave the best total polyphenol content with $326.05 \pm 117.90 \mathrm{mg}$ EAG / g of extract and showed the best result on the DPPH radical with an inhibition of $73.33 \pm 1.46 \%$ which is statistically equal to that of gallic acid used as a reference.
\end{abstract}

These extracts showed good antibacterial activity by inhibiting the quorum sensing system. Thus, they could therefore be used for the manufacture of anti-quorum sensing phytomedicines without a bactericidal effect.

Keywords: Anti-quorum sensing; Violacein; Biofilm; Sclerocarya birrea; Sterculia setigera

\section{Introduction}

P. aeruginosa is an opportunistic bacterium with little or no virulence in healthy individuals but which can prove to be formidable in subjects with weakened immunity. The bacteria can activate a complex regulatory cascade leading to the simultaneous production of several virulence factors, when a certain population density is reached. This type of global

\footnotetext{
${ }^{*}$ Corresponding author: Dramane Paré

Laboratory of Biochemistry and Applied Chemistry (LABIOCA), UFR/SVT, 09 BP 848, Ouagadougou 09, University of Ouagadougou, Ouagadougou, Burkina Faso.

Copyright (@ 2021 Author(s) retain the copyright of this article. This article is published under the terms of the Creative Commons Attribution Liscense 4.0.
} 
regulation is called quorum sensing. The virulence of $P$. aeruginosa linked to quorum sensing. Furthermore, $P$. aeruginosa cells are also capable of associating with each other to form a heterogeneous structure called a biofilm. Bacteria in the biofilm are very resistant to antibiotics [1]. Over $80 \%$ of medical bacterial infections treated by physicians in developed countries are caused by organisms growing in biofilms [2].

The abuse of antibiotics creates selective pressure, leading to the widespread development of resistant bacterial strains [3]. Faced with the ineffectiveness of antibiotics in eliminating bacteria, there is a growing need for the discovery and development of antimicrobial agents which exhibit new or unexplored properties to effectively control and manage infectious bacterial diseases [4].

Inhibition of bacterial virulence and / or biofilm formation by targeting non-microbicidal mechanisms are examples of increasingly explored antipathogenic approaches [5]. Thus, medicinal plants inhibitors of quorum sensing have already been found. Okusa et al. [6] found that extracts of Cordia gilletii from wild (Boraginaceae) suppress the Quorum Sensing of Pseudomonas aeruginosa PA01. The extract of Forsythia suspense inhibits the production of violacein in $C$. violaceum 12472 and also inhibits the production of virulence factors regulated by quorum sensing and biofilm formation in $P$. aeruginosa in a concentration-dependent manner [7].

Sclerorarya birrea and Sterculia setigera are two plants used in traditional medicine in Burkina Faso. According to Braca, A et al. [8].the stem bark, roots and leaves of $S$. birrea are used to treat hypertension, diabetes, dysentery and inflammation. The acetone extracts of $S$. birrea showed remarkable bactericidal activity against $\mathrm{H}$. pylori killing more than $50 \%$ of the strains [9]. The bark of the species has also shown antibacterial activity against Escherichia coli and Salmonella typhi. [10].Several bioactive compounds have been isolated from $S$. birrea extract such as ellagic acid, Naringenin, Rhamnetine, quercetin [11]. Extracts of sterculia setigera have shown good antioxidant and antiinflammatory activity in vivo and in vitro and weak cytotoxic effect on African green monkey kidney cells (Vero cells) $[12,13]$. Akin-Osanaiye, B. C. et al., [14] showed that $S$. setigera species inhibited the growth of bacteria such as $P$. aeruginosa, $S$. aureus and E. coli. The phytochemical study revealed the presence of alkaloids, flavonoids, phenolic compounds and glycosides.

The objective of this study is to determine the inhibitory potential of virulence factors (quorum sensing system) of Chromobacterium violaceum CV026 and Pseudomonas aeruginosa PA01 by Sclerorarya birrea and sterculia setigera extracts.

\section{Material and methods}

\subsection{Plant material and extraction}

The leaves of Sclerocarya birrea and Sterculia setigera were harvested in Kossodo (Ouagadougou, Burkina Faso) in June 2020. The species were authenticated and herbaria were deposited at the UFR / SVT herbarium. The samples were dried under laboratory conditions, out of the sun, then sprayed to obtain the vegetable powder.

The powder $(50 \mathrm{~g}$ ) of each plant material was placed in bottles containing $500 \mathrm{ml}$ of absolute ethanol. The bottles were subjected to mechanical shaking for $24 \mathrm{~h}$ at laboratory room temperature. The macerates were filtered and then concentrated in an evaporator fitted with a vacuum pump and then evaporated to dryness. These extracts are kept and used for the various tests

\subsection{Bacterial strains and growth conditions}

P. aeruginosa PA01 and C. violaceum CV026 strains used to assess anti-QS activity were provided from the Laboratoire de Biotechnologie Végétale (Université Libre de Bruxelles, Gosselies, Belgium). Both strains were grown in LuriaBertani (LB) broth medium at $37^{\circ} \mathrm{C}$ for PA01 and $30^{\circ} \mathrm{C}$ for $\mathrm{CV} 026$

\subsection{Anti-Qorum Sensing activity}

\subsubsection{Inhibition of violacein production assay}

Inhibition of violacein production in C. violaceum CV026 was tested according to Choo, J. H. and al. [15]. The production of violacein in the mutant C. violaceum CV026 was induced by adding exogenous N-hexanoyl-L-homoserine (HHL). An overnight culture of C. violaceum CV026 after dilution was added to plant extracts dissolved in DMSO $(100 \mu \mathrm{g} / \mathrm{mL}$ final concentration) and supplemented with HHL (10 $\mu \mathrm{M}$ final concentration); and completed with LB broth (5 mL final volume). Tubes were incubated for $48 \mathrm{~h}$ at $30^{\circ} \mathrm{C}$, with $175 \mathrm{rpm}$ agitation. Bacterial turbidity (OD600nm) was measured 
to assess bacterial growth. Violacein quantification was assessed after $48 \mathrm{~h}$ of growth. One mL of bacterial culture was centrifuged at $7000 \mathrm{rpm}$ for $10 \mathrm{~min}$ and the supernatant was discarded. DMSO $(1 \mathrm{~mL})$ was added to the pellets and the solution was vortexed to dissolve violacein. After centrifugation (7000 rpm, $10 \mathrm{~min}$ ), violacein was quantified by measured the absorbance at $575 \mathrm{~nm}$.

\subsubsection{Biofilm Formation and Quantification}

The quantification of biofilm formation was assessed according to the method described by Vandeputte 0. M.and al., [16]. An appropriately dilution $(50 \mu \mathrm{L})$ of $P$. aeruginosa PA01 overnight culture was added to LB medium supplemented with $10 \mu \mathrm{L}$ of extract $(100 \mu \mathrm{g} / \mathrm{mL}$, final concentration) or DMSO in 12- well polystyrene plates. Plates were incubated for $24 \mathrm{~h}$ at $37^{\circ} \mathrm{C}$. After incubation, planktonic bacteria were discarded with the supernatant, and the biofilms were gently washed three times with distilled water and then fixed with $1 \mathrm{~mL}$ of methanol (99\%). After 15 min, the methanol is removed and the plates were dried at room temperature. In order to reveal the presence of biofilm, crystal violet $(0.1 \%$ in water) was added to each tube $(1 \mathrm{~mL})$ for $30 \mathrm{~min}$ at room temperature. Crystal violet was then discarded and biofilm were washed three times with $1 \mathrm{~mL}$ of water. Finally, in order to solubilize the crystal violet, $2 \mathrm{~mL}$ of acetic acid (33\% in water) was added and the absorbance of the solution was read at $590 \mathrm{~nm}$.

\subsection{Phytochemical screening}

The procedures described by Ciulei (1982) [17] were used for the detection of the different chemical groups. Thus: the reaction with iron trichloride $\left(\mathrm{FeCl}_{3}\right)$ is used for the detection of tannins and polyphenols, the Shibata test for flavonoids, the Feiggl-Frehden test for coumarins, the Liebermann / Buchard test for triterpenes / steroids, The foam test for saponosides.

\subsection{Determination of phenolic compounds}

\subsubsection{Determination of total polyphenols}

Total polyphenols were determined using Folin Ciocalteu reagent [18]. A volume of $125 \mu \mathrm{L}$ of methanol extracts (100 $\mu \mathrm{g}$ / $\mathrm{mL}$ ) was mixed with $625 \mu \mathrm{L}$ of Folin- Ciocalteu reagent $(0.2 \mathrm{~N})$. After $5 \mathrm{~min}, 500 \mu \mathrm{L}$ of aqueous sodium carbonate $\left(\mathrm{Na}_{2} \mathrm{CO}_{3}, 75 \mathrm{~g} / \mathrm{l}\right)$ were added. After $2 \mathrm{~h}$ of incubation in the dark at room temperature, the absorbances were measured at $760 \mathrm{~nm}$. A standard calibration curve was plotted using gallic acid (0-50 $\mathrm{gg} / \mathrm{mL})$. The results are expressed in milligrams of gallic acid equivalent per $1 \mathrm{~g}$ of dry extract (mg EAG / $1 \mathrm{~g}$ ).

\subsubsection{Dosage of flavonoids}

The total flavonoid contents of the extract were determined by the colourimetric method [19]. A volume of $75 \mu$ l of $2 \%$ $\mathrm{AlCl}_{3}$ in pure methanol was mixed with an equal volume of $1 \mathrm{mg} / \mathrm{ml}$ extract in methanol. The optical densities were read after $10 \mathrm{~min}$ at $415 \mathrm{~nm}$ using the spectrophotometer. A mixture of $75 \mu \mathrm{l}$ of extract and $75 \mu \mathrm{l}$ of methanol without $\mathrm{AlCl}_{3}$ served as a blank. The results are expressed in milligrams equivalent quercetin for $1 \mathrm{~g}$ of dry extract (mg EQ / $1 \mathrm{~g}$ )

\subsection{Antioxidant activities}

\subsubsection{Anti-radical activity $D P P H$}

The anti-radical activity of the ethanolic extract $(1 \mathrm{mg} / \mathrm{ml})$ was evaluated by the DPPH (2,2 diphenyl-1-picrylhydrazyl) method [20]. This method is based on the reduction in absorbance at $517 \mathrm{~nm}$ of the stable free radical DPPH, in the presence of a hydrogen radical donor [26], three (03) tests were carried out by mixing $100 \mu \mathrm{l}$ of the sample and $200 \mu \mathrm{l}$ of DPPH (20 mg / l in methanol). After 15 minutes of incubation, the absorbance is read at $517 \mathrm{~nm}$ against a blank. The antiradical activity was expressed in percent inhibition.

\subsubsection{Ferric ion reducing potential (FRAP)}

The determination of the reducing power of the plant extract has been evaluated as described by Hinneburg et al., [21]. In test tube containing $0.5 \mathrm{ml}$ of extract ( $1 \mathrm{mg} / \mathrm{ml}), 1.25 \mathrm{ml}$ of phosphate buffer $(0.2 \mathrm{M}, \mathrm{pH} 6.6)$ and $1.25 \mathrm{ml}$ of potassium hexacyanoferrate (1\% aqueous) were added. The mixture was heated at $50^{\circ} \mathrm{C}$ in a bain-marie for 30 minutes. After cooling, trichloroacetic acid (1.25 mL, 10\%) was added, and the mixture was then centrifuged (2000 rpm for 10 minutes). Three aliquots $(125 \mu \mathrm{l})$ of the supernatant were transferred in microplate to which $125 \mu \mathrm{l}$ of distilled water and then $25 \mu \mathrm{l}$ of $\mathrm{FeCl}_{3}(0.1 \%$ aqueous $)$ were added. The reductive power was evaluated at $700 \mathrm{~nm}$ against a standard curve of ascorbic acid. The experiment was carried out in triplicate (independent tests), and the reducing activity of the extract was expressed in mmol Equivalent Ascorbic acid per gram of extract (mmol EAA / g extract). 


\subsection{Statistical Analysis}

All results were expressed as the mean value of several independent experiments $(n=3) \pm$ standard deviation. For statistical analysis, Graph Pad Prism software (version 5.0) and MS Excel software were used to obtain standard curves and graphs, percentages of inhibition, averages and standard deviations. Anova one way followed by the Tukey test was used to measure the degree of statistical significance of the results. A significant difference was considered for $\mathrm{P}<0.05$.

\section{Results and discussion}

\subsection{Anti-quorum sensing activity of extracts}

\subsubsection{Inhibition of violacein production}

The ability of $S$. birrea and S. setigera extracts to reduce the production of violacein produced by $C$. violaceum CV026 was determined as shown in Figure 1. This strain of bacteria is deficient in homoserine-lactone synthase and has was used to determine the anti-quorum sensing activity of the samples. At $100 \mathrm{mg} / \mathrm{ml}$, extracts showed a good reduction in violacein. S. setigera presented the best result with an inhibition of $70.19 \%$ compared to the negative control which is DMSO 1\%. This inhibition is greater than that of ascorbic acid used as a reference product. $S$. birrea presented the lowest value. Extracts of $S$. birrea and $S$. setigera do not inhibit bacterial growth of $C$. violaceum CV026 at a concentration of $100 \mathrm{mg} / \mathrm{ml}$, so it does not affect cell viability (Figure 2)

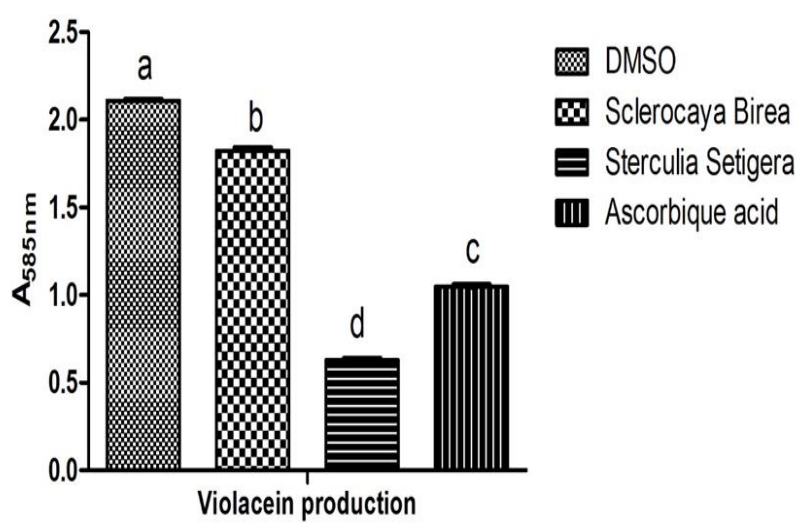

Figure 1 Inhibition of the production of violacein

Results indicated by different letters are statistically distinct ( $p<0.05$; Mean \pm S.E.M $=$ Mean values \pm Standard error of means of three experiments)

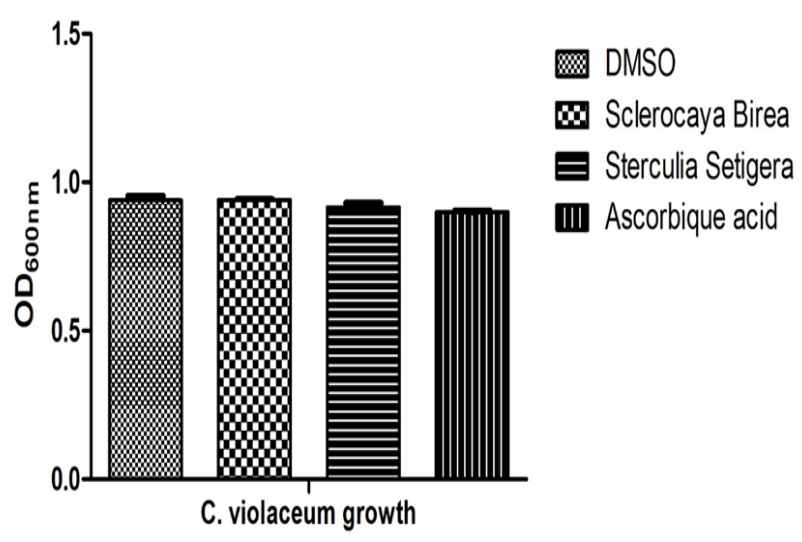

Figure 2 Effect of extracts on bacterial growth $\mathrm{p}<0.05$; Mean \pm S.E.M $=$ Mean values \pm Standard error of means of three experiments 


\subsubsection{Inhibition of bacterial biofilm formation}

The formation of biofilm by the bacterium P. aerusinosa PA01 is one of its virulence factors. The inhibitory potential of biofilm formation by extracts of $S$. birrea and S. setigera after $24 \mathrm{~h}$ of bacterial growth was determined (Figure 3 ). The extract of leaves of $S$. setigera was the most active with an inhibition of $72.24 \%$ compared to the negative control, thus showing a higher activity than that of ascorbic acid used as a positive reference. . Extracts of $S$. birrea and $S$. setigera do not inhibit the bacterial growth of $P$. aerusinosa PA01 (Figure 4), so they do not have a bactericidal effect.

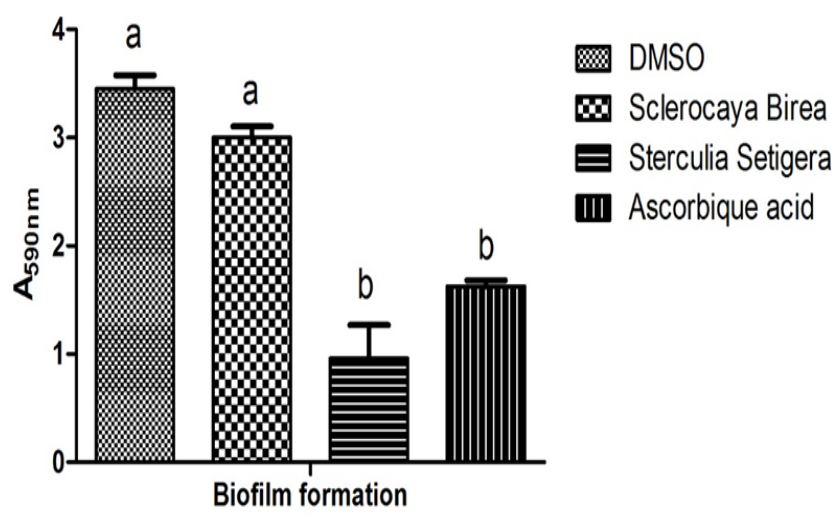

Figure 3 Inhibition of biofilm formation by extracts of $S$. setigera and $S$. birrea.

Results indicated by different letters are statistically distinct $(\mathrm{p}<0.05$; Mean \pm S.E.M $=$ Mean values \pm Standard error of means of three experiments)

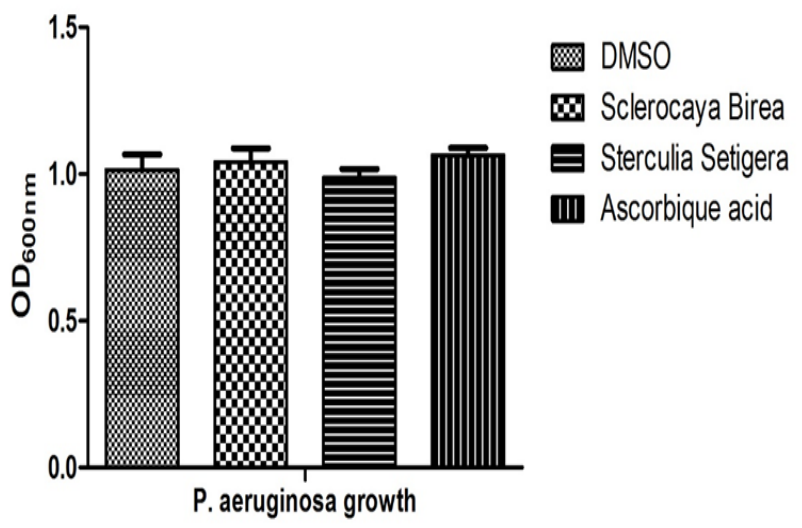

Figure 4 Effect of extracts on bacterial growth of P. aerusinosa

$\mathrm{p}<0.05 ;$ Mean \pm S.E.M $=$ Mean values \pm Standard error of means of three experiments

\subsection{Phytochemical screening}

Phytochemical analysis revealed the presence of phenolic and terpene compounds in extracts of S. setigera and S. birrea (Table 1). Tannins and polyphenol, flavonoids, triterpene, coumarins were detected in both extracts. Saponosides were only detected in $S$. birrea extract

Table 1: Result of phytochemical screening

\begin{tabular}{|l|l|l|l|l|l|}
\hline \multirow{2}{*}{ Plants } & \multicolumn{4}{|l|}{ Result of phytochemical screening } \\
\cline { 2 - 7 } & Tannins and polyphenols & Flavonoïds & Saponosides & Sterols / triterpene & Coumarins \\
\hline S. birrea & + & + & + & + & + \\
\hline S. setigera & + & + & - & + & + \\
\hline
\end{tabular}




\subsection{Determination of phenolic compounds}

Figure 5 shows the contents of total polyphenols and total flavonoids in plant extracts. S. setigera and S. birrea gave total flavonoid contents of $5.83 \pm 1.58 \mathrm{mg} \mathrm{EQ} / 100 \mathrm{mg}$ and $5.15 \pm 0.38 \mathrm{mg}$ EQ / 100mg, respectively, not statistically different (Figure 5B). S. birrea gave the best total polyphenol content with $326.05 \pm 117.90 \mathrm{mg}$ EAG / g extract against $150.51 \pm$ $49.12 \mathrm{mg}$ EAG / g extract for $S$. setigera (Figure $5 \mathrm{~A}$ ).

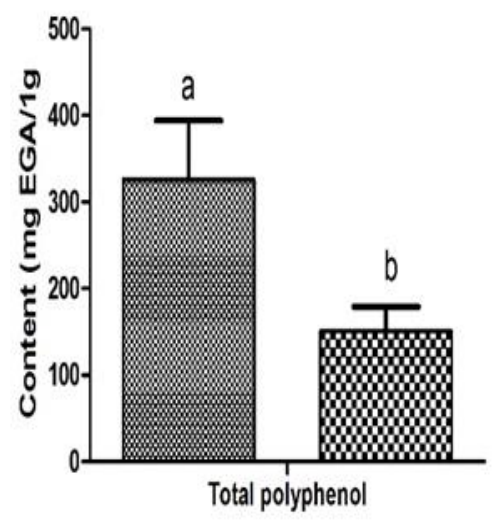

A

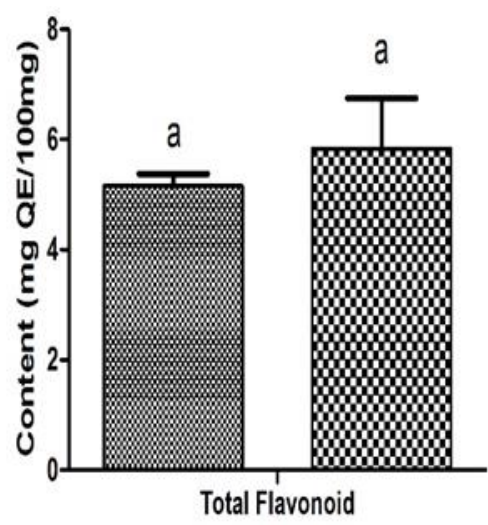

B

Figure 5 Content of total polyphenols and total flavonoids in plant extracts

Results indicated by different letters are statistically distinct $(\mathrm{p}<0.05$; Mean \pm S.E.M $=$ Mean values \pm Standard error of means of three experiments)

\subsection{Antioxidant potential of $S$. birrea and $S$. setigera extracts}

The antioxidant capacity of our extracts have been evaluated by their anti-radical DPPH potential and their ability to reduce ferric ion to ferrous ion (FRAP method). The $S$. birrea extract showed the best result on the DPPH radical with an inhibition of $73.33 \pm 1.46 \%$ which is statistically equal to that of the gallic acid used as a reference. S. sétigera presented the lowest result with $33.18 \pm 0.21 \%$ as inhibition (Figure 6).

For the reducing activity of $\mathrm{Fe}^{3+}$ S. birrea showed a better result with an activity of $18.85 \pm 0.40 \mathrm{mmol}$ EAA / $\mathrm{g}$ of extract against $9.39 \pm 0.27 \mathrm{mmol}$ EAA / g of extract for S. setigera. (Figure 7).

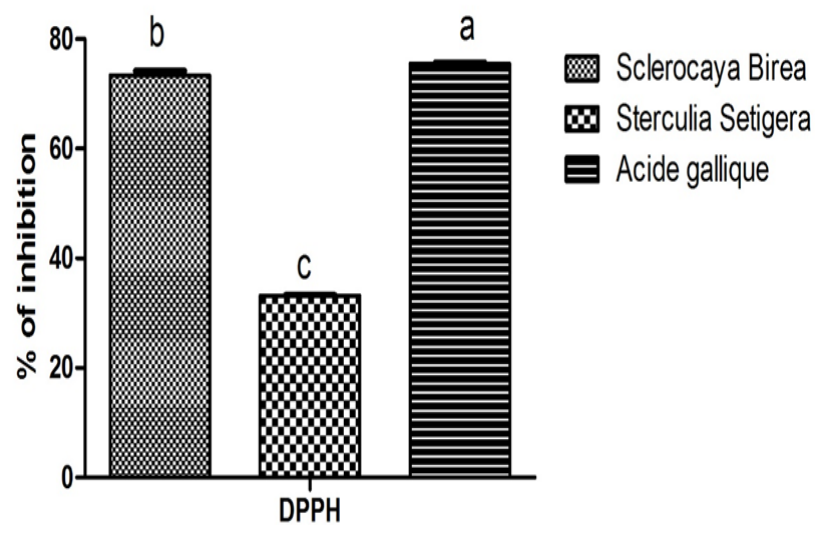

Figure 6 Anti-radical DPPH activity

Results indicated by different letters are statistically distinct $(p<0.05$; Mean \pm S.E.M $=$ Mean values \pm Standard error of means of three experiments) 


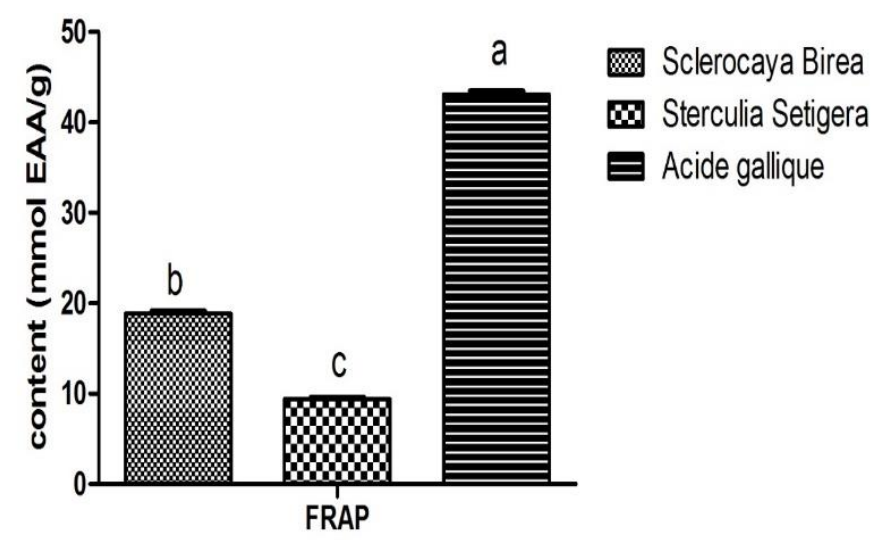

Figure 7 Reducing activity of ferric ion

Results indicated by different letters are statistically distinct $(\mathrm{p}<0.05$; Mean \pm S.E.M $=$ Mean values \pm Standard error of means of three experiments)

\section{Discussion}

In bacteria such as $P$. aeruginosa and $C$. violaceum, virulence factors are regulated by quorum sensing, a global genetic regulatory mechanism dependent on cell density. Interference with quorum sensing circuits is considered a potential strategy to attenuate bacterial pathogenicity.

The production of violacein by $C$. violaceum is regulated by quorum sensing system dependent of the CvilR gene [22]. Thus a modification of the production of violacein by extracts can be considered as evidence of the anti quorum sensing activity thereof. P. aeruginosa PA01, an opportunistic pathogen, uses two interrelated QS systems, LasI / R and RhlI / R, which regulate pyocyanin production, proteolytic, elastolytic activity and biofilm formation [23]. Biofilm formation allows P. aeruginosa to be protected against host defenses and antimicrobial agents [24].

This biofilm formation inside the host has enabled the successful establishment of pathogens and the development of chronic infections in humans [25].

Extracts of $S$. setigera and S. birrea showed good anti quorum sensing activity with a $70.19 \%$ inhibition of violacein formation for $S$. setigera greater than that of ascorbic acid used as a reference. These extracts also reduced the biofilm formation of $P$. aeruginosa without a bactericidal effect. Ratul Sarkara et al., [26] showed that $S$. birrea reduced the biofilm formation of $P$. aeruginosa with $75 \%$ inhibition, these results corroborate our results obtained. By inhibiting the production of violacein and biofilm, our samples could have acted on the regulatory genes involved in quorum sensing.

These plant extracts having shown a significant inhibition of the formation of biofilm mediated by quorum sensing, thus demonstrating the possible application of these plants in the management of persistent, chronic or recurrent infections (where the biofilms offer a persistent resistance to common antibiotics. used) [27].

Flavonoids, polyphenols, tannins, terpenes have been detected in our samples. Our results corroborate with those of Lawaly M. M., and al., and Akin-Osanaiye, B. C., and al.. [10,14]. The extracts of S. setigera and S. birrea showed a good content of total flavonoids and total polyphenols. Studies have already demonstrated the anti quorum sensing activity of phenolic compounds.

Curcumin from Curcurma longa attenuates the biofilm formation of P. aeruginosa PA01 [28]. Flavones have shown good anti quorum sensing activity by reducing the production of violacein by Chromobacterium violaceum [29]. Kaempferol showed anti-quorum sensing activity against $C$. violaceum and $P$. aeruginosa PA01 at $100 \mu \mathrm{g} / \mathrm{mL}$ [30]. Elagic acid, tannic acid and epigallocatechin gallate inhibit biofilm production by interfering with the production signals of $\mathrm{N}$-acylhomoserine lactones which is a molecule involved in quorum sensing. Thus, the presence of phenolic compounds in extracts of $S$. birrea and $S$. setigera could explain the good anti-quorum sensing activity observed.

In this study the plant extracts showed good capacity for scavenging free radicals and reducing metal cations. Metal cations such as calcium, magnesium and iron have been implicated in maintaining and strengthening the integrity of the biofilm matrix [31]. Together with the antioxidant properties of the extracts, they could chelate or reduce the metal 
cations involved in maintaining the integrity of the biofilm matrix and thus affect this integrity. This could explain the inhibition of biofilm formation by plant extracts.

S. birrea and S. setigera could therefore be used as an antimicrobial agent acting on the quorum sensing system without bactericidal effect to limit the development of resistance to infectious agents

\section{Conclusion}

From this study it emerges that the extracts of $S$. birrea and $S$. setigera exhibited anti-quorum sensing activities by inhibiting the production of violacein from $C$. violaceum and the formation of biofilm by P. aeruginosa PA01 and also showed a potential interesting antioxidant. The phytochemical study revealed the presence of flavonoids, tannins, triterpenes, saponosides, coumarin in the extracts. These plant species can therefore be used in the treatment of pathologies resistant to antibiotics. For what follows, it would be interesting to determine the mechanism of action of the extracts on quorum sensing molecules, such as $\mathrm{N}$-acyl-homoserine lactone.

\section{Compliance with ethical standards}

\section{Acknowledgments}

This work was supported by Laboratory of Biochemistry and Applied Chemistry in Burkina Faso

\section{Disclosure of conflict of interest}

Authors have declared that no competing interests exist.

\section{References}

[1] Brown MR, Allison DG, Gilbert P. Resistance of bacterial biofilms to antibiotics: a growth-rate related effect? J Antimicrob Chemother. 1988; 22: 777-780.

[2] Schaudinn C, Gorur A, Keller D, Sedghizadeh PP, Costerton JW. Periodontitis: an archetypical biofilm disease. J Am Dent Assoc. 2009; 140: 978-986.

[3] English BK, Gaur AH. The use and abuse of antibiotics and the development of antibiotic resistance. Advances in Experimental Medicine and Biology. 2010; 659: 73-82.

[4] Cegelski L, Marshall GR, Eldridge GR, Hultgren SJ. The biology and future prospects of antivirulence therapies. Nature Reviews Microbiology. 2008; 6(1): 17-27.

[5] Kalia VC, Purohit HJ. Quenching the quorum sensing system: potential antibacterial drug targets, Critical Reviews in Microbiology. 2011; 37(2): 121-140.

[6] Okusa PN, Rasamiravaka T, Vandeputte O, Stévigny C, Jaziri ME, Duez P. Extracts of Cordia gilletii de wild (Boraginaceae) quench the quorum sensing of Pseudomonas aeruginosa PA01. J Intercult Ethnopharmacol. $2014 ; 3: 138-43$.

[7] An Zhang, Wei-Hua C. Anti-Quorum Sensing Activity of Forsythia suspense on Chromobacterium violaceum and Pseudomonas aeruginosa. Pharmacogn Mag. 2017; 13(50): 321-325.

[8] Braca A, Politi M, Sanogo R, Sanou H, Morelli I, Pizza C, de Tommasi N. Chemical composition and antioxidant activity of phenolic compounds from wild and cultivated Sclerocarya birrea (Anacardiaceae) leaves. J. Agric. Food Chem. 2003; 51: 6689-6695.

[9] Collise N, Afolayan AJ, Roland N.N. Aqueous and Organic Solvent-Extracts of Selected South African Medicinal Plants Possess Antimicrobial Activity against Drug-Resistant Strains of Helicobacter pylori: Inhibitory and Bactericidal Potential. Int. J. Mol. Sci. 2011; 12: 5652-5665.

[10] Lawaly MM, Diallo HB, Idrissa M, Khalid I. Phytochemical Screening and Antibacterial Activity of Stem Bark, Leaf and Root Extract of Sclerocarya birrea (A. Rich.) Hochst. Int J Enteric Pathog. 201 ; 5(4): 127-131.

[11] María de la Luz C, Jesús L, Álvaro F, Antonio S. Enhancing the Yield of Bioactive Compounds from Sclerocarya birrea Bark by Green Extraction Approache. Molecules. 2019; 24(966): 1-15. 
[12] Nahla MMT, Barakat MM. Antioxidant and cytotoxic activities of Sterculia setigera Del. American journal of Research Communication. 2018; 6(5): 41-49.

[13] Isaac TH, Robertson A, Elvis OA, Daniels K, George O, Bashiru A, Joseph A, Fred JE, Francis T. Stem Bark Extract of Sterculia setigera Delile Exhibits Anti-inflammatory Properties through Membrane Stabilization, Inhibition of Protein Denaturation and Prostaglandin E2 Activity. Journal of Pharmaceutical Research International. 2018; 22(5): 1-11.

[14] Akin-Osanaiye BC, Yusuf MK, (2018). Phytochemical Screening and Antibacterial Activity of Leaves of Sterculia Setigera Extracts. Direct Res. J. Biol. Biotechnol. Sci. 2018; 4(4): 40-45.

[15] Choo JH, Rukayadi Y, Hwang JK. Inhibition of bacterial quorum sensing by vanilla extract. Lett. Appl. Microbiol. 2006; 42: 637-641.

[16] Vandeputte OM, Kiendrebeogo M, Rajaonson S, Diallo B, Mol A, El Jaziri M, Baucher M. "Identification of catechin as one of the flavonoids from Combretum albiflorum bark extract that reduces the production of quorumsensingcontrolled virulence factors in Pseudomonas aeruginosa PA01. Appl. Environ. Microbiol. 2010; 76(1): $243-253$.

[17] Ciulei I. (1982). Pratical manuals on the industrial utilization of chemical and aromatic plants. Methodology for analysis of vegetable drugs Ed. ministry of chemical industry, Bucharest. 1982.

[18] Singleton VL, Orthofer R, Lamuela-Raventos RM. Analysis of phenols and other oxidation substrates and antioxidants by means of Folin-Ciocalceu Reagent. Methods in Enzymology. 1999; 299: 152-178.

[19] Arvouet-Grand A, Vennat B, Pourrat A, Legret P. Standardisation d'un extrait de propolis et identification des principaux constituants. J. de Pharm. de Belgique. 1994; 49(6): 462-468.

[20] Velazquez E, Tournier HA, Mordiyavich-Buschiazza P, Saavedra G, Schinnella GR. Antioxydant activity of Paraguayan plants extracts. Fitoterapia. 2003; 74: 91-97.

[21] Hinneburg I, Damien-Dordan HJ, Hiltunen R. Antioxidant activities of extracts from selected culinary herbs and spices. Food Chemistry. 2006; 97(1): 122-129.

[22] McLean RJC, Pierson LS, Fuqua C. A simple screening protocol for the identification of quorum signal antagonists. J. Microbiol. Methods. 2004; 58: 351-360.

[23] Smith RS, Iglewski BH. Pseudomonas aeruginosa quorum sensing systems and virulence. Curr Opin Microbiol. 2003; 6: 56-60.

[24] Rasamiravaka T, Vandeputte OM, Pottier L, Huet J, Christian R, Kiendrebeogo M, Andriantsimahavandy A, Rasamindrakotroka A, Stévigny C, Duez P, El Jaziri M. Pseudomonas aeruginosa biofilm formation and persistence, along with the production of quorum sensing-dependent virulence factors, are disrupted by a triterpenoid coumarate ester isolated from Dalbergia trichocarpa, a tropical legume. PLoS One. 2015; 10(7): $1-32$.

[25] Annapoorani A, Kalpana B, Musthafa KS, Pandian SK, Ravi AV. Antipathogenic potential of Rhizophora spp. against the quorum sensing mediated virulence factors production in drug resistant Pseudomonas aeruginosa. Phytomedicine. 2013; 20: 956-963.

[26] Ratul S, Sushil KC, Amrita S, Kirendra KY, Neelesh KN, Mamello S, Sanmoy K, Fernão CB, Motlalepula GM, Pulok KM, Tuhinadri S. Anti-biofilm activity of Marula - A study with the standardized bark extract. Journal of Ethnopharmacology. 2014; 154: 170-175.

[27] Burmølle M, Thomsen TR, Fazli M, Dige I, Christensen L, Homøe P, Tvede M, Nyvad B, Tolker-Nielsen T, Givskov M, Moser C, Kirketerp-Møller K, Johansen HK, Høiby N, Jensen PO, Sørensen SJ, Bjarnsholt T. Bioflms in chronic infections - a matter of opportunity - monospecies bioflms in multispecies infections. FEMS Medical Microbiology and Immunology. 2010; 59: 324-333.

[28] Rudrappa T, Bais HP. Curcumin, a known phenolic from Curcuma longa, attenuates the virulence of Pseudomonas aeruginosa PA01 in whole plant and animal pathogenicity models. J. Agric. Food Chem. 2008; 56(6): $1955-1962$.

[29] Malena ES, Sonja K, Suvi M, Pia MV, Adyary F. Flavones as Quorum Sensing Inhibitors Identified by a Newly Optimized Screening Platform Using Chromobacterium violaceum as Reporter Bacteria. Molecules. 2016; 21(1211): 1-11. 
World Journal of Biology Pharmacy and Health Sciences, 2021, 05(01), 009-018

[30] Vasavi HS, Arun AB, Rekha P-D. Anti-quorum sensing activity of Psidium guajava L. flavonoids against Chromobacterium violaceum and Pseudomonas aeruginosa PAO1. Microbiology and Immunology. 2014; 58(5): 286-293.

[31] Abdel-aziz SM, Aeron A, 2014. Bacterial biofilm: dispersal and inhibition strategies stages of biofilm development. SAJ Biotechnol. 2014; 1(1): 19. 